\title{
Zinc Polypyrrole-air Sea Water Battery
}

\author{
A.H. Al-Eggiely ${ }^{1}$, A.A. Alguail, ${ }^{1}$,M.M. Gvozdenović ${ }^{1}$, B.Z. Jugović ${ }^{2}$, B.N. Grgur, ${ }^{1, *}$ \\ ${ }^{1}$ Faculty of Technology and Metallurgy, University of Belgrade, Karnegijeva 4, 11020 Belgrade, \\ Serbia \\ ${ }^{2}$ Institute of Technical Sciences of the Serbian Academy of Sciences and Arts, Knez Mihailova 35/IV, \\ 11000 Belgrade, Serbia \\ *E-mail: BNGrgur@tmf.bg.ac.rs
}

doi: $10.20964 / 2016.12 .35$

Received: 9 September 2016 / Accepted: 30 September 2016 / Published: 10 November 2016

\begin{abstract}
An environmentally friendly cell using polypyrrole-air regenerative cathode and zinc as anode, is investigated in the $3.5 \%$ sodium chloride solution for the possible applications as the sea water cell. It is shown that cell can deliver constant current in the range of tens of milliamps per gram of polypyrrole, and in the range of hundreds of milliamps under impulse discharge mod, with the cell voltage above $0.8 \mathrm{~V}$, over significant period of time. It is suggested that cell could be considered, at least as a secondary power in a remote sensor buoy system for the monitoring shallow marine environments.
\end{abstract}

Keywords: Conducting polymers; Air regenerative cathode; Buoy; Metal-air battery

\section{FULL TEXT}

(C) 2016 The Authors. Published by ESG (www.electrochemsci.org). This article is an open access article distributed under the terms and conditions of the Creative Commons Attribution license (http://creativecommons.org/licenses/by/4.0/). 